\section{УДК: $351 / 354$}

https://doi.org/10.32689/2617-22242020-2(22)-177-184

\section{Піх Наталія Степанівна,} аспірант, Начіональна Академія державного управління при Президентові України, 20, вул. Ежена Потьє, м. Київ, 02000, +3806759628 55, dobvit2@gmail.com, https//orcid.org/0000-0001-6261-8461

\section{Пих Наталья Степановна,} аспирант, Национальная Академия государственного управления при Президенте Украины, 20, ул. Эжена Потье, г. Киев, 02000, +3806759628 55, dobvit2@gmail. com, https//orcid.org/0000-0001-62618461

\section{Pikh Nataliya Stepaniona,}

Postgraduate Student, National Academy of Public Administration under the President of

Ukraine, 20, Eugene Potier Str., Kyiv, 02000, +38067596 28 55, dobvit2@gmail.com, https// orcid.org/0000-0001-6261-8461

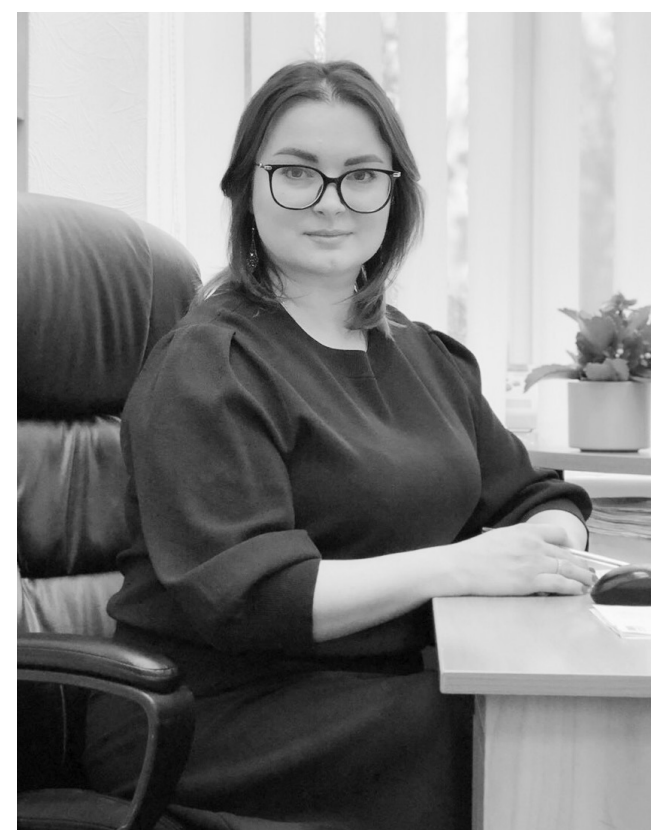

\title{
ЗАБЕЗПЕЧЕННЯ ГРОМАДСЬКОЇ (ПУБЛІЧНОЇ) БЕЗПЕКИ НА АМЕРИКАНСЬКОМУ КОНТИНЕНТІ
}

Анотація. 3 використанням загальнонаукових методів емпіричного пізнання досліджено особливості здійснення державної політики у сфері забезпечення громадської (публічної) безпеки у країнах Американського континенту. Розкрито особливості забезпечення громадської (публічної) безпеки, які обумовлені політичними, інституційними, географічними, історичними факторами, окреслено концептуальні засади забезпечення громадської (публічної) безпеки, виявлені актуальні тенденції та виокремлено конкретні практичні заходи, спрямовані на підтримку громадського порядку.

Досліджено сучасний стан забезпечення громадської (публічної) безпеки у країнах Американського континенту, який базується на налагодженні партнерських зв’язків державних органів публічної влади, органів місцевого самоврядування із громадськими та неурядовими організаціями, науковими колами, окремими громадянами. Визначено рівні та інституції, на яких здійснюється забезпечення громадської безпеки в країнах Американського континенту та пріоритетні напрями державної політики, а саме профілактика та запобігання подій, що можуть становити реальну небезпеку для широ- 
кої громадськості. Проаналізовано заходи інституційного, організаційного та спеціального характеру, які покликані об'єднати зусилля усіх зацікавлених сторін і оптимізувати матеріально-технічні витрати на забезпечення громадської безпеки країн Американського континенту.

Доведено, що досвід країн Американського континенту в забезпеченні громадської (публічної) безпеки являє собою комплекс заходів щодо забезпечення належного захисту. Для цього вживаються низка інституційно-організаційних заходів, які покликані об’єднати зусилля усіх зацікавлених сторін. Обгрунтовано пропозиції щодо здійснення державної політики у сфері громадської (публічної) безпеки у країнах Американського континенту.

Ключові слова: громадська (публічна) безпека, США, Канада, громадський порядок, державна політика, місцеве самоврядування, органи державної влади.

\section{ОБЕСПЕЧЕНИЕ ОБЩЕСТВЕННОЙ (ПУБЛИЧНОЙ) БЕЗОПАСНОСТИ НА АМЕРИКАНСКОМ КОНТИНЕНТЕ}

Аннотация. С использованием общенаучных методов эмпирического познания исследованы особенности реализации государственной политики в сфере обеспечения общественной (публичной) безопасности в странах Американского континента. Раскрыты особенности обеспечения общественной (публичной) безопасности, которые обусловлены политическими, институциональными, географическими, историческими факторами, очерчены концептуальные основы обеспечения общественной (публичной) безопасности, выявлены актуальные тенденции и выделены конкретные практические меры, направленные на поддержание общественного порядка.

Исследовано современное состояние обеспечения общественной (публичной) безопасности в странах Американского континента, которое базируется на налаживании партнерских связей государственных органов публичной власти, органов местного самоуправления с общественными и неправительственными организациями, научными кругами, отдельными гражданами. Определены уровни и институты, на которых осуществляется обеспечение общественной безопасности в странах Американского континента и приоритетные направления государственной политики, а именно профилактика и предупреждение событий, которые могут представлять реальную опасность для широкой общественности. Проанализированы меры институционального, организационного и специального характера, которые призваны объединить усилия всех заинтересованных сторон и оптимизировать материально-технические затраты на обеспечение общественной безопасности стран Американского континента.

Доказано, что опыт стран Американского континента в обеспечении общественной (публичной) безопасности представляет собой комплекс мер по обеспечению надлежащей защиты Для этого употребляются ряд институционально-организационных мероприятий, которые призваны объединить усилия всех заинтересованных сторон. Обоснованы предложения по реали- 
зации государственной политики в сфере общественной (публичной) безопасности в странах Американского континента.

Ключевые слова: общественная (публичная) безопасность, США, Канада, общественный порядок, государственная политика, местное самоуправление, органы государственной власти.

\title{
PROVIDING SOCIAL (PUBLIC) SECURITY IN THE AMERICAN CONTINENT
}

\begin{abstract}
The article uses the general methods of empirical cognition to study the peculiarities of implementing the public policy in the field of social (public) security in the countries of the American continent. The peculiarities of providing the social (public) security, which are caused by the political, institutional, geographical, historical factors, the conceptual foundations of ensuring social (public) security, the actual trends and the specific practical measures aimed at maintaining the public order are revealed. The current state of providing social (public) security in the countries of the American continent is investigated, which is based on establishing partnerships between the public authorities, local selfgovernment bodies with public and non-governmental organizations, academia, and individual citizens. The levels and institutions at which the public security in the American continent is implemented and the priorities of the public policy are identified, namely the prophylaxis and prevention of events that may present a real danger to the general public. Institutional, organizational and special measures are designed to unite the efforts of all stakeholders and to optimize the logistical expenditures for the public security in the American continent. It has been proven that the experience of the American continent in providing social (public) security is a set of measures to ensure adequate protection. To this end, a series of institutional and organizational measures are being taken to unite the efforts of all stakeholders. The proposals for the implementation of the public policy in the field of social (public) security in the American continent are substantiated.
\end{abstract}

Keywords: Social (public) security, USA, Canada, public order, public policy, local government, public authorities.

Постановка проблеми. В умовах поглиблення глобалізації та інтеграції політичних, економічних, соціальних та інших процесів в світі, особливу зацікавленість викликають питання, пов'язані із забезпечення громадської (публічної) безпеки країн. Вивчення досвіду країн Американського континенту у забезпеченні громадської (публічної) без- пеки є важливим не лише для теорії, а й передусім для практичної його імплементації в Україні. Унікальність підходів до забезпечення громадської (публічної) безпека США і Канади пов'язана як із новітніми інституційними мінливостями так і 3 історичними особливостями розвитку країн, що підвищує важливість та затребуваність наукових досліджень 
за допомогою виявлення причинно-наслідкових зав'язків. Сучасний підхід країн Американського континенту у забезпеченні громадської (публічної) безпеки базується на налагодженні партнерських зв’язків державних органів публічної влади, органів місцевого самоврядування із громадськими та неурядовими організаціями, науковими колами, окремими громадянами.

Аналіз останніх досліджень i публікацій. Дослідженням різних аспектів проблематики забезпечення громадської (публічної) безпеки присвячено праці вітчизняних та зарубіжних вчених: О. Бандурки, В. Василевича, Дж. Джокела, В. Дрьоміна, О. Костенко, В. Манжоли, К. Носсала, Г. Перепелиці, Н. Хіллмера, О. Шостко та ін. Однак, в Україні існує порівняно невелика кількість з означеної вище проблематики, що обумовлює актуальність подальшого її вивчення.

Постановка завдання. Опрацювання представленої проблематики забезпечення громадської (публічної) безпеки країн Американського континенту вимагає постановки низки наукових завдань, які потребують ретельного дослідження, а саме дослідити організаційно-правові аспекти громадської безпеки на міжнародному рівні. Метою дослідження є аналіз досвіду країн Американського континенту у сфері забезпечення громадської (публічної) безпеки.

Виклад основного матеріалу. Аналіз останніх років підвищення рівня громадської (публічної) безпеки в США дає підстави стверджувати про ефективність реалізації державної політики в цьому напрямі. Означені тенденції є результатом взаємодії органів державної влади, місцевого самоврядування та громадськості.

Забезпечення громадської безпеки в США здійснюється на наступних рівнях: національному (митнатаприкордоннаслужбаСШАUnited States Customs and Border Protection (CBP); федеральне агентство 3 надзвичайних ситуації - The Federal Emergency Management Agency (FEMA); федеральне бюро розслідувань - The Federal Bureau of Investigation (FBI) тощо); регіональному (міська поліція; поліція округу; відділ шерифа; державна або провінційна поліція тощо); локальному (пожежна бригада; місцевій поліцейський орган або відділ; мерія; управління муніципальних громадських справ тощо)[1-9].

Забезпечення громадської безпеки в США передбачає професійну діяльність у наступних інститутах: правоохоронні органи (національна або федеральна поліція, регіональна або місцева поліція); інтелектуальна діяльність та обмін інформацією (розвідка, слідчі дії, таємні операції); управління надзвичайними ситуаціями (швидка медична допомога, пожежна служба, поліція, пошук та рятівні роботи); правосуддя (суди, юридичні адміністрації, пенітенціарна система); внутрішньодержавне забезпечення (прикордонні та портові структури, берегова охорона, надання адміністративних послуг) [5].

В США громадська (публічна) безпека розглядається, насамперед, як функція уряду щодо забезпечення належного захисту громадян, мешканців певного регіону, місцевих організацій та установ від загроз їхньо- 
му благополуччю та процвітанню. Для цього вживаються відповідні заходи інституційного, організаційного та спеціального характеру, які покликані об'єднати зусилля усіх зацікавлених сторін і оптимізувати матеріально-технічні витратами на забезпечення громадської безпеки. Організація громадської безпеки передбачає надання громадянам правоохоронних, пожежних та невідкладних медичних послуг. Пріоритетним напрямом є профілактика та запобігання подій, що можуть становити реальну небезпеку для широкої громадськості.

Враховуючи зазначене вище, проаналізуємо сучасний стан забезпечення громадської (публічної) безпеки в США державної політики в цій країні.

Вагомий внесок забезпечення громадської (публічної) безпеки в США та здійснення політики в цій сфері.

Сучасний стан забезпечення громадської (публічної) безпеки в США сформувався під впливом наступних факторів: прийняття закону "The Violent Crime Control and Law Enforcement Act” та реалізації відповідних заходів [1]; демографічних особливостей (старінням населення), яке природно призвело до зменшення кримінальної активності; активізації громадського впливу на підвищення рівня громадської (публічної) безпеки в країні, ефективної взаємодії органів державної влади, місцевого самоврядування та громадськості. За висновками ООН, у США лише 25 \% показник зниження злочинності можна пов'язати із каральною практикою органів влади, решта - із забезпеченням охорони громадського порядку силами громад, профілактикою злочинності й змінами в системі зайнятості населення [2].

Пріоритетним напрямом здійснення державної політики щодо забезпечення громадської (публічної) безпеки США є реалізація урядових програм профілактичного спрямування які приймаються як на федеральному так і на місцевому рівнях. В цілому такі програми включають в себе організацію профілактичних заходів та розробку напрямів соціологічних досліджень, боротьбу з тероризмом. До спеціальних органів взаємодії у сфері забезпечення громадської (публічної) безпеки США, в яких громадськість є одним із основних суб'єктів, відносяться: Консультативна виправна рада; Комітет по боротьбі із злочинністю молоді та неповнолітніх при Президентові США; Міжвідомча рада щодо координації національних програм боротьби із злочинністю молоді; Національна консультативна рада із запобігання зловживання алкоголю; Національний центр безпеки у школах тощо [9]. Кількість таких програм на теперішній час в США більше сотні. Урядом США за підтримки Конгресу розроблено міжнародні та національні програми щодо боротьби 3 тероризмом як у США, так і в світі. Концепція цих програм базується на посиленні ролі держави у забезпечення громадської (публічної) безпеки, навіть за рахунок об'єктивного обмеження прав і свобод громадян в інтересах як національної, так й особистої безпеки. В рамках реалізації цих програм активізувалися місцеві ініціативи громадян США щодо 
пропозицій поліпшення системи безпеки в країні. Громадськість США з розумінням поставилася до цих обмежень, в реалізації антитерористичної політики Уряду США. Яскравим прикладом ефективної взаємодії органів державної влади, місцевого самоврядування з громадськими інститутами у здійсненні боротьби з тероризмом є програма "Сусідський дозор" ("Neighborhood Watch"), яка реалізована за ініціативи Національної асоціації шерифів США. Програма націлена на підтримку громадян, які інформують поліцію про підозрілі дії колег по роботі, сусідів, інші випадки. Громадські активісти разом із правоохоронцями проводили агітаційні заходи щодо правил поведінки у випадку надзвичайних ситуацій, фахові тренінги та презентаціï.

Ще одним прикладом ефективної та взаємовигідної взаємодії органів державної влади, місцевого самоврядування 3 громадськими інститутами з метою забезпечення громадської (публічної) безпеки США є програма "Нагорода за справедливість”, яку реалізується за ініціативи Державного департаменту США. За програмою, свідомі громадяни, мета яких жити у безпечному штаті, своєчасно повідомляють про підготовку терористичного акту або про місце знаходження терористів. За прояв громадянської позиції та свідомості їм виплачується грошова винагорода. Програма одразу показала свою ефективність: протягом першого року виконання була припинена діяльність великої кількості організацій і приватних осіб, підозрюваних у допомозі терористам.
У США діє низка інституцій, які займаються забезпеченням громадської безпеки, серед яких: міжнародна асоціація співробітників антитерористичних відомств, діяьність якої має на меті безпосереднє залучення та підтримка активних громадян до боротьби з тероризмом з метою вирішення цієї проблеми на міжнародному рівні. Асоціація сприяе формуванню у суспільстві єдиного розуміння тероризму, характеру заходів, що здійснюються державою для боротьби з ним. У складі Міжнародної асоціації співробітників антитерористичних відомств входять фахівці різних служб безпеки різних країн. В рамках роботи Асоціації була започаткований напрям антитерористичної освіти школярів, у рамках якої підростаюче покоління засвоювало правила поведінки в екстремальних ситуаціях; неурядова організація добровільних помічників поліції “Crime Stoppers”. Ї̈̈ відділення крім США працюють в Австралії, Великій Британії, Польщі, Канаді, країнах Латинської Америки; програма громадського наставництва "Великі браття, великі сестри" (Big Brothers Big Sisters) - метою є залучення добровольців-волонтерів, тобто наставників для роботи з неповнолітніми, які є вихідцями із неблагополучних сімей. Програма об'єднує близько 400 агенцій по всій країні.

Розглядаючи та аналізуючи досвід забезпечення громадської (публічної) безпеки в Канаді, доцільно звернути увагу на розвиток американсько-канадських міжнародних відносин. Спільна історія та географія на багато років поєднали ці країни, що суттєво вплинуло на здійс- 
ненні їх державної політики, в тому числі й в сфері безпеки. Д. Баррі та Д. Братт, аналізуючи питання безпеки звертають увагу на те, що „канадсько-американська безпека характеризується взаємозалежністю. Як наслідок, Канада не тільки не може ігнорувати вимоги США у сфері безпеки, але і відокремитися від наслідків американських рішень у даній сфері” [4]. Офіційна позиція цих країни щодо забезпечення безпеки базується на взаємодії та співробітництві, яке офіційно було закріплене Огденсбурзькою угодою. За роки такого тісного союзництва між США та Канадою було створено низку механізмів двосторонньої співпраці: укладено понад 80 угод у сфері безпеки, понад 250 меморандумів про порозуміння, створено близько 145 двосторонніх форумів, на яких обговорюються актуальні проблеми у сфері безпеки та оборони [4]. Високий рівень стратегічного значення співробітництва США та Канади у сфері безпеки значно зміцнює позиції Канади у північноамериканській системі безпеки, надає право голосу та впливу на прийняття рішень, а також доступ до відповідної інформації та технологій. Важливим чинником забезпечення безпеки на американському континенті є членство Канади та США у НАТО. Аналізуючи канадсько-американські відносини в сферах безпеки та оборони, Д. Лейтон-Браун окреслює унікальну особливість: “Канада більше схильна до “публічної дипломатії” у разі незгоди зі Сполученими Штатами щодо проблем безпеки та оборони, що стосуються альянсу загалом, на багатосторонньому рівні, аніж іздвосторонніх проблем” [6]. “Оттава більше схильна до так званої “тихої дипломатії” [4]. Таким чином, в контексті геополітичного простору канадсько-американські відносини у сфері забезпечення безпеки можна охарактеризувати як дружні, рівні та взаємовигідні. Хоча, для об'єктивності суджень, доцільно звернути увагу на значну перевагу рівня впливу Сполучених Штатів на прийняття рішень альянсу НАТО, й геополітичного впливу в цілому.

Висновки. Підсумовуючи вищевикладене, варто зазначити, що досвід країн Американського континенту у забезпеченні громадської (публічної) безпеки являє собою комплекс заходів щодо забезпечення належного захисту Для цього вживаються низка інституційно-організаційних заходів, які покликані об'єднати зусилля усіх зацікавлених сторін.

\section{СПИСОК ВИКОРИСТАНИХ ДЖЕРЕЛ}

1. Бандурка О. М. Партнерські взаємовідносини між населенням та міліцією : підручник / О. М. Бандурка, В. О. Соболєв, В. І. Московець. Х. : Вид-во Нац. ун-ту внутр. справ, 2016. $352 \mathrm{c}$.

2. Глобалізація і безпека розвитку : монографія / О. Г. Білорус, Д. Г. Лук'яненко та ін. ; керівн. авт. кол. і наук. ред. О. Г. Білорус. Київ : КНЕУ, 2017. 733 c.

3. Ліпкан B. A. Національна і міжнародна безпека у визначеннях та поняттях : словник / В. А. Ліпкан, О. С. Ліпкан. [2-ге вид., допов. і переробл. Київ : Текст, 2018. 400 с.

4. Granatstein J. Canada and the United States: Security and Strategic Interests after 9/11// New Zealand 
International Review. JanuaryFebruary 2018. Vol. 33, № 1. P. 1114.

5. Crime in the United States - 2018 [Електронний ресурс]. Режим доступу : https:// crime-in-the-u.s.-2014/ offensesknown-to-law-enforcement/ violent-crime

6. Mauer M. Comparative international rates of incarceration: an examination of causes and trends / paper presented to the United States Commision on Civil Rights. Washington, D. C., 25 June 2017; A/Conf.206/17/Workshop 2: Strategies and Best Practices for Crime Prevention, in particular in relation to Urban Areas and Youth at Risk // Eleventh United Nations Congress on Crime Prevention and Criminal Justice (Bangkok, Thailand, 13-14 April 2017). 28 p.

7. Official website of the United States Department of Homeland Security (DHS). Our Mission [Електронний pecypc]. Режим доступу: https:// www.dhs.gov/our-mission

8. The Queensland Fire and Emergency Services (QFES). Website. [Електронний ресурс]. Режим доступу: https://www.qfes.qld.gov.au/Pages/ default.aspx

9. Sokolsky J. J. The "Away Game" : Canada - United States Security Relations Outside North America // IRPP Working Paper Series. 2004. № 91. P. 1-7.

\section{REFERENCES}

1. Bandurka O. M., Soboliev V. O., Moskovets V. I. (2016). Partnerski vzaiemovidnosyny mizh naselenniam ta militsiieiu [Partnership relations between the population and the police]. Kharkiv: Vyd-vo Nats. un-tu vnutr. sprav [in Ukrainian].
2. Bilorus O. H., Lukianenko D. H., et al. (2017). Hlobalizatsiia $i$ bezpeka rozoytku [Globalization and development security]. Kyiv: KNEU [in Ukrainian].

3. Lipkan V. A., Lipkan O. S. (2018). Natsionalna $i$ mizhnarodna bezpeka $u$ vyznachenniakh ta poniattiakh [National and international security in definitions and concepts]. ( $2^{\text {nd }}$ ed., rew.). Kyiv: Tekst [in Ukrainian].

4. Granatstein J. (2018). Canada and the United States: Security and Strategic Interests after 9/11. New Zealand International Review, 33(1), 11-14 [in English].

5. Crime in the United States. (n.d.). crime-in-the-u.s.-2014. Retrieved from https://crime-in-the-u.s.-2014/ offensesknown-to-law-enforcement/ violent-crime [in English].

6. Mauer M. (2017). Comparative international rates of incarceration: an examination of causes and trends. Workshop 2: Strategies and Best Practices for Crime Prevention, in particular in relation to Urban Areas and Youth at Risk: Eleventh United Nations Congress on Crime Prevention and Criminal Justice. Bangkok [in English].

7. Our Mission (The United States Department of Homeland Security (DHS). wrw.dhs.gov. Retrieved from https://www.dhs.gov/our-mission [in English].

8. Official Website of the Queensland Fire and Emergency Services (QFES). wrow.qfes.qld.gov.au. Retrieved from https://www.qfes.qld.gov.au/Pages/ default.aspx [in English].

9. Sokolsky J. J. (2004). The "Away Game": Canada - United States Security Relations Outside North America. IRPP Working Paper Series, 91, 1-7 [in English]. 